\author{
Weidong Wang ${ }^{\mathrm{a}}$, \\ Dali Wang ${ }^{a}$, \\ Chengqing Yin ${ }^{a}$ \\ a State Key Laboratory of \\ Environmental Aquatic \\ Chemistry, Research Center \\ for Eco-Environmental \\ Sciences, CAS, P.O. Box 2871, \\ Beijing, 100085, P. R. China
}

\section{A Field Study on the Hydrochemistry of Land/Inland Water Ecotones with Reed Domination}

The hydrochemistry of land/water ecotones dominated by a reed (Phragmites australis) community was studied in a eutrophic shallow lake in China. The ecotones are composed of reed beds divided by many artificial ditches and serve as a connecting link between the upstream Fuhe River mouth and the downstream central lake. This lake-side ecotone exhibited a strong chemical buffering function and high nutrient removal processes. In the subsurface water of reed beds, the partial $\mathrm{CO}_{2}$ pressure was $23 . . .704$ times of that in the atmosphere and the partial $\mathrm{O}_{2}$ pressure was $5 \ldots 34 \%$ of atmospheric $\mathrm{O}_{2}$ pressure. The change of hydrochemical type and greatest nutrient reduction occurred at $0.5 \mathrm{~m}$ landward from the reed-bed/ditch boundary. The dominant cations in ditch water and subsurface water were $\mathrm{Na}^{+}$and $\mathrm{Ca}^{2+}$, respectively. The nutrient level in the reed-bed subsurface water maintained low and stable despite the variable high concentrations of nutrients in the ditch water. The crisscrossed reed-bed/ditch landscape greatly increases the active area between eutrophic river mouth water and subsurface water. Since the area of reed fields in the lake occupies $22 \%$ of the lake area, the exchange between the subsurface water of reed beds and ditches can act as a huge buffer to reduce allochthonous nutrient input and the nutrient concentrations in the lake. Thus, the self-purification capacity of the lake ecosystem increased with the presence of an active ecotone.

Eine Feldstudie zur Hydrochemie von Land/Binnengewässer-Übergangsgebieten, dominiert von Röhricht

Untersucht wird die Hydrochemie eines Land/Wasser-Ökotons, dominiert von einem Röhricht (Phragmites communis), in einem eutrophen Flachsee in China. Die Ökotone bestehen aus Röhrichtbeeten, geteilt durch künstliche Gräben, und dienen als Bindeglied zwischen der Mündung des River Fuhe und dem Zentrum des Sees. Diese Übergangsregion zwischen Land und See zeigt eine stark puffernde Funktion mit hohem Nährstoffrückhalt. Im Bodenwasser der Röhrichtbeete betragen die Partialdrücke des $\mathrm{CO}_{2}$ das 23...704fache und des $\mathrm{O}_{2} 5 \ldots 34 \%$ der atmosphärischen Drücke. Die Änderung des hydrochemischen Typs und stärkste Reduzierung der Nährstoffe tritt 0.5 m landwärts der Grenze zwischen Beet und Kanal ein. Die dominanten Kationen im Kanalwasser bzw. Bodenwasser sind $\mathrm{Na}^{+}$bzw. $\mathrm{Ca}^{2+}$. Der Nährstoffgehalt des Bodenwassers innerhalb des Röhrichts bleibt niedrig und stabil unabhängig von den wechselnd hohen Konzentrationen in den Kanälen. Die Landschaft aus dem Gewirr von Kanälen und Röhrichtbeeten vergrößert die aktive Zone zwischen dem eutrophen See und dem Bodenwasser erheblich. Da das Gebiet der Röhrichtfelder 22\% der Seefläche beträgt, arbeitet der Austausch zwischen Bodenwasser und Kanälen als sehr großer Puffer zur Reduzierung des allochthonen Nährstoffeintrages auf die Nährstoffkonzentration im See. Dadurch nimmt die Selbstreinigungskapazität des Gesamtökosystems See mit derartig aktiven Ökotonen zu.

Keywords: Water Chemistry, Retention, Subsurface Water, Reed Bed, Ditch, Ecotone

Schlagwörter: Nährstoffrückhalt, Bodenwasser, Röhrichtbeet, Kanalwasser, Ökoton

Correspondence: C. Yin, E-mail: cqyin@mail.rcees.ac.cn 


\section{Introduction}

Land/inland water ecotones are dynamic components of the landscape and important regulators of material movement across landscapes [1]. They exist and functionate over broad spatial and temporal scales. In recent years, the study of landwater interactions has emerged as a critical focus for modern environmental scientists as well as water resources managers [2]. Ecotones serve as buffer zones between terrestrial and aquatic ecosystems, and are an instrument for the amelioration of surface water quality. Many studies have demonstrated that ecotone wetlands can effectively control agricultural non-point source pollution [3-7]. The ecotone interface can act as a strong physical and biological buffer to reduce nutrient movements to receiving waters. However, many interfacial zones are sensitive to environmental changes [8, 9], possessing the ability to act as chemical sources or sinks depending on the different ambient conditions [10].

Scientists have focused primarily on the hydrology of wetlands since they determine the establishment and maintenance of specific types of wetlands and wetland processes. Eser and Rosen [11] studied the hydrochemistry of Stump Bay wetland and found that the reduction of ferric iron determines many hydrochemical variations in the groundwater. Hite and Cheng [12] investigated the chemical interactions between wetland plants and groundwater by characterizing the spatial variation in hydrogeochemical parameters and showed that the reactions determined by the activity of plant roots and soil microorganisms can affect the spatial distribution of hydrogeochemical parameters. The hydrochemical gradients of the aquatic-terrestrial interface can greatly determine the purification efficiency of wetland ecosystems [13]. However, few comprehensive studies about hydrology and hydrochemistry of ecotones and wetlands have been reported $[11,14]$.

Ecotones composed of reed communities and ditches are found to be effective in reducing the allochthonous nutrient input to receiving lake waters [15]. However the hydrochemical actions occurring in such ecotones are not well known. We conducted field studies in the eutrophic river mouth of Baiyangdian Lake, an area critical for maintaining lake water stability. We hypothesized that the shallow ditch is an extension of the aquatic boundary of ecotones and the reed bed is the extension of the terrestrial boundary. We show the hydrochemical processes in ditches and subsurface water of reed beds, and the interactions between terrestrial and aquatic boundaries.

\section{Study sites}

The field experimental sites were located in Baiyangdian Lake, the largest natural freshwater body in North China

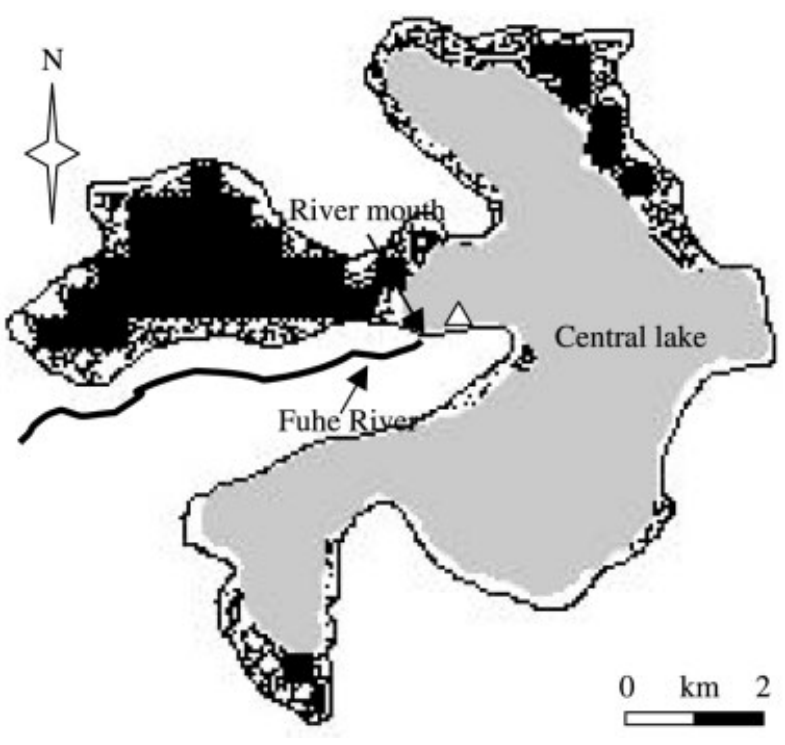

Fig. 1: Map of Baiyangdian Lake, the grey area represents water area and the dotted dark area describes the area which is being converted into cultivated farmland. The triangle refers to the location of study sites.

Karte des Baiyangdian Lake. Grau - die Wasseroberfläche, dunkel punktiert - landwirtschaftlich kultivierte Flächen, Dreieck - Untersuchungsgebiet.

Plain. It is located $130 \mathrm{~km}$ south of Beijing and covers a surface area of $366 \mathrm{~km}^{2}$. Baiyangdian Lake is a decaying lake with the water area being reduced due to local land till activity, and is in a eutrophic state. The lake depth is usually less than $2 \mathrm{~m}$, but variable depending on the hydrologic conditions. During certain dry years, the lake only retains a small amount of water and typically exhibits swamp-like conditions. The dominant macrophyte vegetation is the common reed Phragmites australis with a height of roughly $3 \mathrm{~m}$. Nymphoides peltatum, Lemna minor are distributed in the marginal waters around the reed community. In addition, other vegetation such as Scirpus yagara, Scirpus juncoides, Butomus umbellatus, and Juncellus serotinus coexist with the dominant reed. In Baiyangdian Lake, reed fields occupy 8000 ha, accounting for $22 \%$ of the lake area. These vegetation constitute the emerging community with a biomass density of $3 \ldots 5 \mathrm{~kg} / \mathrm{m}^{2}$. More than 3700 artificial ditches divide the reed fields into multiple beds. The reed beds usually have a width of $30 \ldots 40 \mathrm{~m}$ and the ditches of $5 \ldots 10 \mathrm{~m}$. During moderate flow conditions, water moves freely in the ditches; these ditches act as multiple corridors in the reed bed landscape. The edge area of reed beds and ditches is easily influenced by the undulation of water flow and provides a good exchange of water and matter between the reed bed soil and ditch water. 
Table 1: Selected properties in the profile of reed bed soil.

Ausgewählte Eigenschaften im Bodenprofil der Röhrichtbeete.

\begin{tabular}{|c|c|c|c|c|c|}
\hline & $\begin{array}{l}\text { Soil horizon } \\
\text { Depth, cm }\end{array}$ & $\begin{array}{c}A \\
0 \ldots 12\end{array}$ & $\begin{array}{c}\mathrm{Ag} \\
12 \ldots .25\end{array}$ & $\begin{array}{c}\mathrm{Bg} \\
25 \ldots 35\end{array}$ & $\begin{array}{c}\mathrm{B} / \mathrm{Cg} \\
35 \ldots 50\end{array}$ \\
\hline \multirow[t]{5}{*}{ Physical and chemical properties } & Texture & Loamy clay & Clay & Clay & Clay \\
\hline & Bulk density, $\mathrm{g} / \mathrm{cm}^{3}$ & 1.13 & 1.22 & 1.34 & 1.51 \\
\hline & $\mathrm{pH}$ & 8.0 & 8.0 & 8.0 & 8.0 \\
\hline & Effective exchange capacity, meq/100 g soil & 22.6 & 26.4 & 29.4 & 25.6 \\
\hline & Calcium carbonate, $\%$ & 14.7 & 6.29 & 7.38 & 5.24 \\
\hline \multirow[t]{6}{*}{ Nutrients } & Organic matter, \% & 3.94 & 1.87 & 1.76 & 1.36 \\
\hline & Total nitrogen, \% & 0.22 & 0.11 & 0.10 & 0.079 \\
\hline & $\mathrm{C} / \mathrm{N}$ & 8.75 & 8.90 & 8.12 & 9.39 \\
\hline & Total phosphorus, \% & 0.067 & 0.066 & 0.062 & 0.061 \\
\hline & Hydrolysable nitrogen, mg/kg & 137 & 52 & 42 & 48 \\
\hline & Bioavailable phosphorus, mg/kg & 11 & 3 & 3 & 3 \\
\hline
\end{tabular}

A: A horizon; Ag: surface gley horizon; Bg: hydromorphic glei horizon; B/Cg: alluvial/glei C horizon.

Field experiments were carried out between May...June, Oct....Dec. 2000 and Aug....Sept. 2001. Ten reed beds in the lake near the Fuhe River mouth (Fig. 1), a major pollution source to the Baiyangdian Lake, were selected as experimental sites; their distance to the river mouth is $650 \ldots 1500 \mathrm{~m}$. Six sites were water locked all around and surrounded by sloping fields with soft gradients at the edge of reed beds, and the remaining four sites resembled the peninsula. Generally, shallow ditches are the circumambience around reed beds. The ditches are connected to main watercourses in Baiyangdian Lake and exhibited similar hydrochemistry. The reed beds are usually $0.5 \ldots 2.5 \mathrm{~m}$ higher than the water level; height variability was dependent on the hydrologic conditions. Some properties in the soil profile of reed community are listed in Table 1.

\section{Experimental methods}

The ditch water samples were collected from the surface layer just at the boundary between the ditch and reed bed. To collect the subsurface water, we used a self-made soil auger $(\phi=11.5 \mathrm{~cm})$ to dig several vertical holes at set distances in the reed beds (Fig. 2). When subsurface water seepage began, additional $50 \mathrm{~cm}$ were excavated for convenient water sampling. The sampling holes were distributed from the edge to the center part of reed beds. Since water exchange at the edge area is more extensive, more holes were distributed at the sloping field. To prevent atmospheric disturbance, prior to sampling, stagnant water in each sampling hole was removed three times and the water level allowed to recover to its natu- ral level. Then the subsurface water was drawn from the holes by a suction pump. During water sampling operation, we were careful to avoid soil disturbance. For three of the experimental sites, water sampling was conducted at three different dates

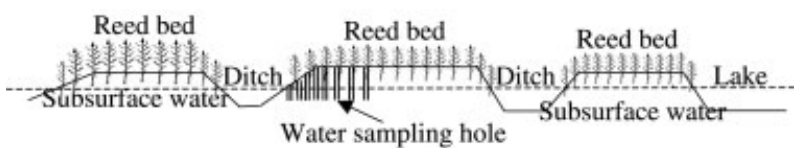

Fig. 2a: The profile of reed-bed/ditch system composed of ditches with width of $5 \ldots 10 \mathrm{~m}$ and reed beds with width of $30 \ldots 40 \mathrm{~m}$.

Das Profil des Systems aus Röhrichtbeeten (30...40 m Breite) und Kanälen (5...10 m Breite).

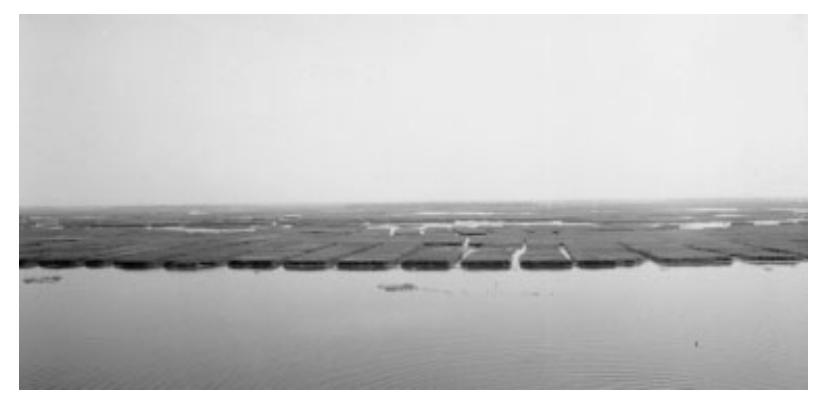

Fig. 2b: One part of the reed-bed/ditch system in Baiyangdian Lake.

Teilansicht des Systems aus Röhrichtbeeten und Kanälen im Baiyangdian Lake. 
within 10 days, and for the remaining seven sites, samples were obtained at two dates over a 25-day interval. All water was sampled between 14:00 $\mathrm{h}$ and 16:00 h.

Subsurface water samples were placed in acid-washed polyethylene bottles. Dissolved oxygen (DO), pH, and temperature $\left({ }^{\circ} \mathrm{C}\right)$ were measured in situ. Magnesium $\left(\mathrm{Mg}^{2+}\right)$, calcium $\left(\mathrm{Ca}^{2+}\right)$, chloride $\left(\mathrm{Cl}^{-}\right)$, sulfate $\left(\mathrm{SO}_{4}^{2-}\right)$, alkalinity $\left(\left[\mathrm{HCO}_{3}^{-}\right]+\left[\mathrm{CO}_{3}^{2-}\right]\right)$, free carbon dioxide $\left(\mathrm{CO}_{2}\right)$, nitrogen (ammonia $\left[\mathrm{NH}_{4}^{+-} \mathrm{N}\right]$, nitrate $\left[\mathrm{NO}_{3}^{-} \mathrm{N}\right]$, nitrite $\left.\left[\mathrm{NO}_{2}^{-}-\mathrm{N}\right]\right)$, phosphorus (total reactive phosphorus [TRP]) were determined with standard methods [16]. Total nitrogen (TN) and total phosphorus (TP) in water samples were determined simultaneously by peroxodisulfate oxidation [17]. The additive content of $\mathrm{Na}^{+}+\mathrm{K}^{+}$was calculated from the difference and subtraction method [18]. The ion analyses were conducted within 8 hours after sample collection in a field laboratory. We calculated the partial pressure of $\mathrm{CO}_{2}$ in the water following Henry's law. The partial pressure of dissolved oxygen in the water was calculated by the saturation degree and saturated partial pressure of atmospheric $\mathrm{O}_{2}$ near the lake water.

Unless otherwise noted, all significant differences are at a probability of 0.05 or less. Coefficient of variation $(\mathrm{CV})$ is adopted to compare the variation degree between different indices.

\section{Results}

\subsection{Water quality status}

Although the central portion of Baiyangdian Lake is not seriously polluted, the lake quality near the Fuhe River mouth is highly impacted (Table 2). The Chinese environmental quality standard for surface water (GHZB 1-1999) [19] classifies the surface water into five grades from good to bad. A first grade water represents source and national nature reserve conditions, and a fifth grade water describes a quality suitable for agricultural irrigation. The lake water quality near the Fuhe River mouth is categorized as a fifth grade. Historically, large quantities of pollutants from Fuhe River have been transported to the river mouth, leading to long-term pollutant accumulations in the mouth area. Diffuse pollutants from the ambient lake-side villages further degrade the river mouth water quality. TN and TP in the river mouth are higher than those in Fuhe River. When the river mouth water flows through the sinuous ditches, water quality has improved. The central part of the lake water roughly achieved the 5 th grade water standards. Pollutant concentrations decreased substantially from river mouth to the center part of the lake.

\subsection{Main ions in the lake and subsurface water}

Figure $3 \mathrm{~A}-\mathrm{F}$ shows the main ion concentrations in ditch water $(0 \mathrm{~m})$ and subsurface water for sites within $18 \mathrm{~m}$ from the edge. The statistical results are given in Table 3. Hydrogencarbonate is the dominant anion in both ditch water and subsurface water of reed beds. Its mean concentration is $333.5 \mathrm{mg} / \mathrm{L}$ in ditch water and $558.6 \mathrm{mg} / \mathrm{L}$ in subsurface water, accounting for $43.1 \%$ and $45.7 \%$ of total ion content in $\mathrm{mg} / \mathrm{L}$. The dominant cation in the ditch water is $\mathrm{Na}^{+}+\mathrm{K}^{+}$ (22.1\% of equivalents), while the subsurface water is dominated by $\mathrm{Ca}^{2+}$ ( $25.1 \%$ of equivalents). Calcium and hydrogencarbonate increased gradually with distances away from ditch water (Fig. 3A, F). Magnesium similarly showed a slight increase (Fig. $3 \mathrm{~B}$ ). $\mathrm{Ca}^{2+}$ and $\mathrm{Mg}^{2+}$ values are correlated with each other $\left(R^{2}=0.7044\right)$ and $\mathrm{HCO}_{3}^{-}$is closely correlated to $\mathrm{Ca}^{2+}\left(R^{2}=0.7805\right)$. For sodium and potassium, chloride, and

Table 2: Water quality data in Fuhe River, river mouth, ditch water, and central lake in 2000 and the standard values for fifth grade surface water.

Daten zur Wasserbeschaffenheit im Fuhe River, an der Flussmündung, im Wasser der Kanäle und im Zentrum des Sees im Jahr 2000 sowie Standardwerte für Oberflächenwasser der fünften Beschaffenheitsklasse.

$\begin{array}{lll}\text { Fuhe River } \quad \text { River mouth } \quad \text { Citch water lake } & \begin{array}{r}\text { Fifth grade } \\ \text { surface wate } \\ \text { standards }\end{array}\end{array}$

\begin{tabular}{lccccc}
\hline Transparency, cm & $21 \pm 8$ & $26 \pm 10$ & $35 \pm 10$ & $96 \pm 11$ & $\geq 50$ \\
$\mathrm{TP}, \mathrm{mg} / \mathrm{L}$ & $1.57 \pm 0.61$ & $2.08 \pm 0.56$ & $0.697 \pm 0.425$ & $0.057 \pm 0.025$ & $\leq 0.12$ \\
$\mathrm{TN}, \mathrm{mg} / \mathrm{L}$ & $18.3 \pm 7.1$ & $25.2 \pm 11.0$ & $14.5 \pm 10.2$ & $1.77 \pm 0.48$ & $\leq 1.2$ \\
$\mathrm{BOD}_{5}, \mathrm{mg} / \mathrm{L}$ & $24.4 \pm 15.8$ & $11.0 \pm 13.2$ & $8.3 \pm 3.8$ & $1.69 \pm 0.44$ & $\leq 10$
\end{tabular}




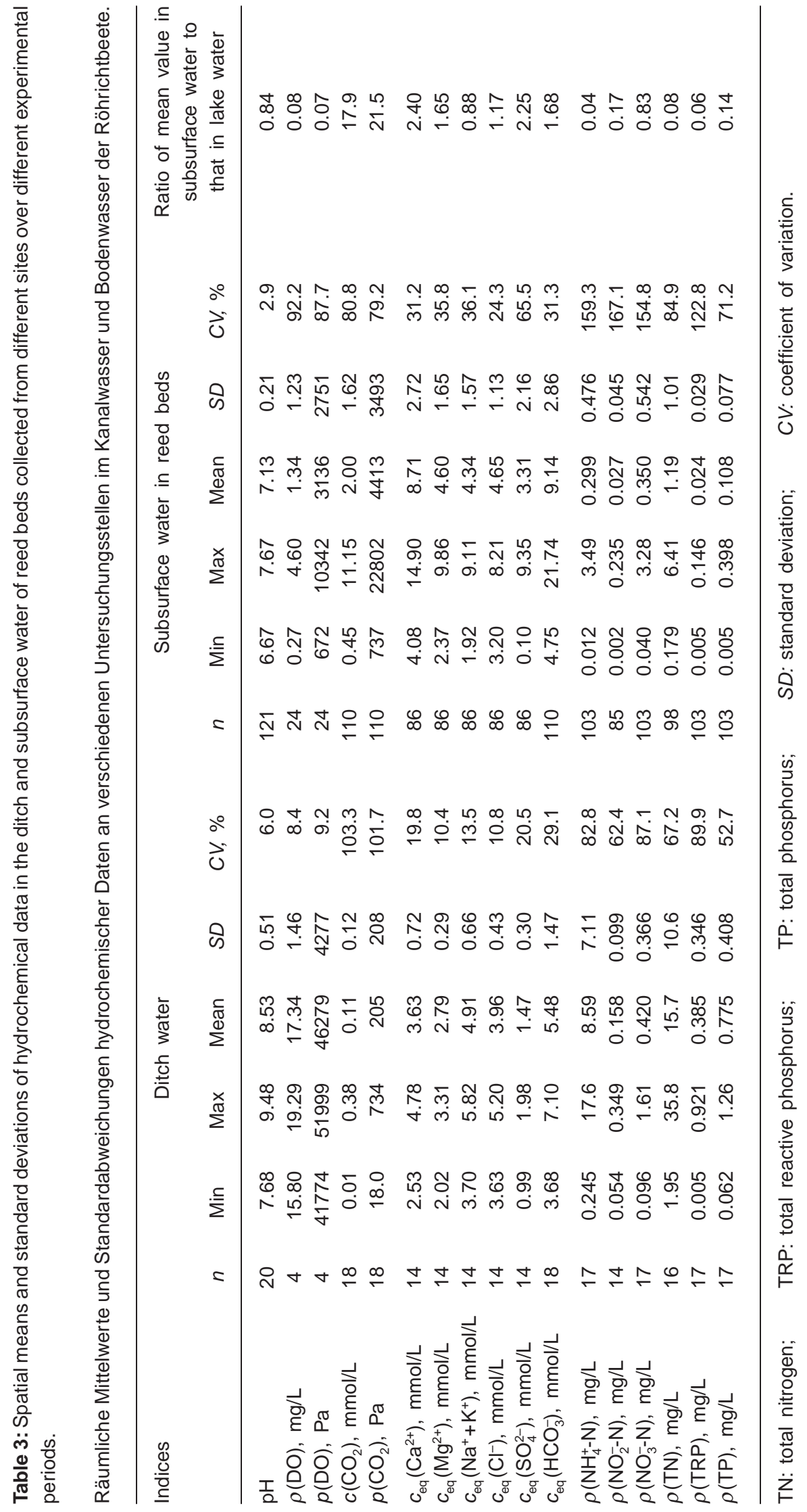


sulfate, the variation of concentration was dispersive (Fig. 3C, D, and E). There are different variation curves for different sites. In some sites, $\mathrm{Cl}^{-}$was nearly constant from the edge to the center of reed beds and for others, $\mathrm{Cl}^{-}$increased gradually with distances. Except for $\mathrm{Na}^{+}+\mathrm{K}^{+}$in some sites, the mean ion concentration in the subsurface water was generally higher than that in the ditch water, and the ratio of concentration ranged from $1.17\left(\mathrm{Cl}^{-}\right)$to $2.40\left(\mathrm{Ca}^{2+}\right)$. The coefficients of variation $(\mathrm{CV})$ for ions in the subsurface water were larger than those in the ditch water. The greatest CVs are found in $\mathrm{HCO}_{3}^{-}$for the ditch water and $\mathrm{SO}_{4}^{2-}$ for the subsurface water. Compared to the ditch water, the proportion of $\mathrm{Ca}^{2+}$ in the subsurface water increased about $10 \%$ and $\mathrm{Na}^{+}+\mathrm{K}^{+}$decreased nearly $10 \%$.

\subsection{The concentrations and partial pres- sures of $\mathrm{CO}_{2}$ and $\mathrm{O}_{2}$}

The $\mathrm{CO}_{2}$ concentration in the ditch water ranged from $0.01 \mathrm{mmol} / \mathrm{L}$ in summer to $0.38 \mathrm{mmol} / \mathrm{L}$ in winter, and the corresponding partial pressure was between $18 \mathrm{~Pa}$ and $734 \mathrm{~Pa}$ (Table 3). The atmospheric pressure of $\mathrm{CO}_{2}$ near the surface water was $32.4 \mathrm{~Pa}$. The $\mathrm{CO}_{2}$ partial pressure in the ditch water was $0.6 \ldots 23$ times of atmospheric $\mathrm{CO}_{2}$ pressure. In contrast with the ditch water, the $\mathrm{CO}_{2}$ concentration in the subsurface water ranged over a larger scale, from 0.45 to $11.15 \mathrm{mmol} / \mathrm{L}$. The partial $\mathrm{CO}_{2}$ pressure increased dramatically from $737 \mathrm{~Pa}$ to $22802 \mathrm{~Pa}$, a range 23...704 times larger than the atmospheric pressure of $\mathrm{CO}_{2}$. The partial pressure of
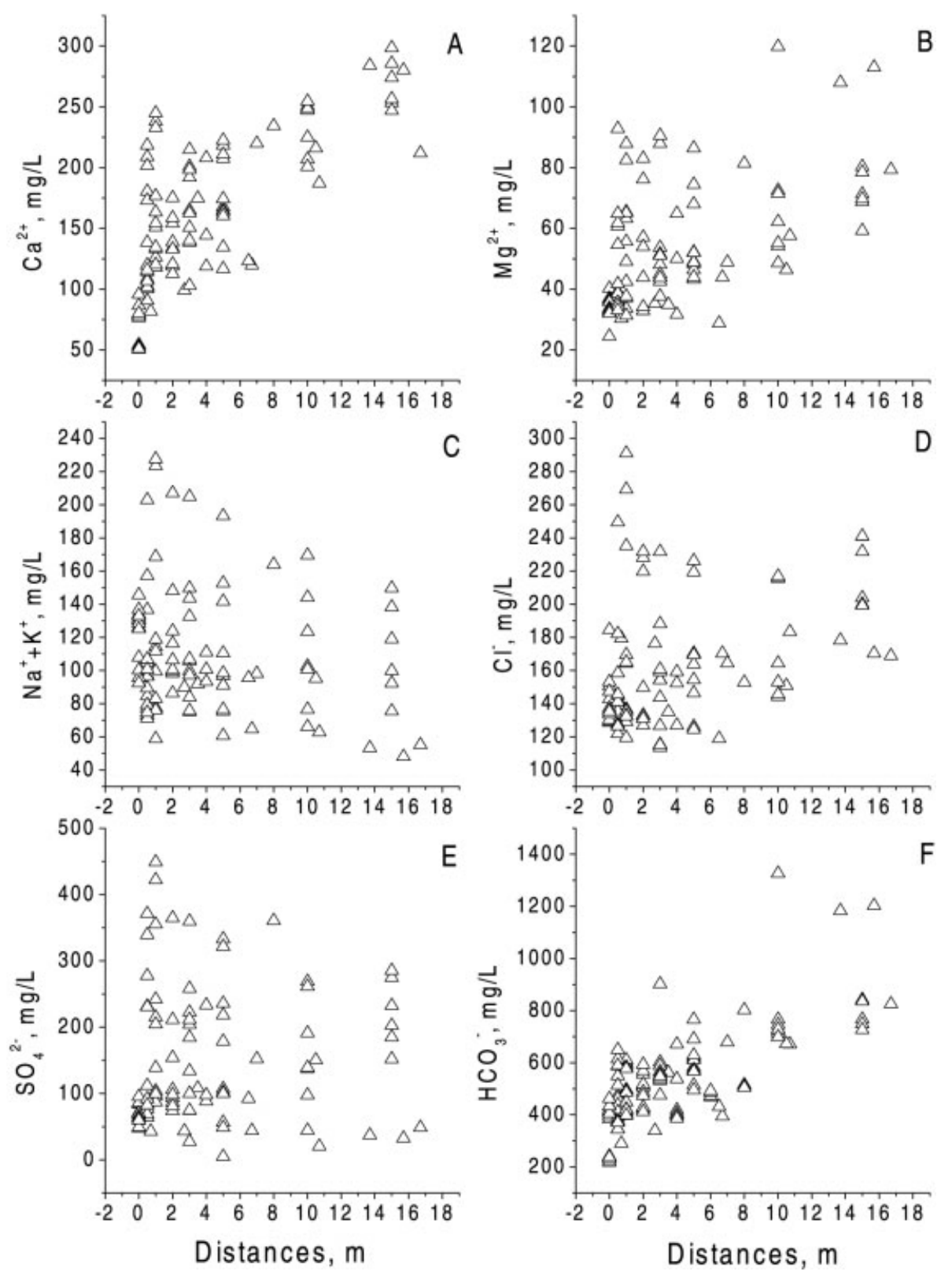

Fig. 3: The concentrations of main ions in the ditch water and subsurface water. Spots at distance $0 \mathrm{~m}$ signify the surface ditch water just at the boundary between ditch and reed bed, and other spots signify the subsurface water samples at distances away from the ditch water boundary towards reed bed.

Konzentrationen der Hauptionen im Kanalwasser und Bodenwasser. Die Abszissenabstände in $\mathrm{m}$ beziehen sich auf die Grenze zwischen Kanal und Röhrichtbeet. 


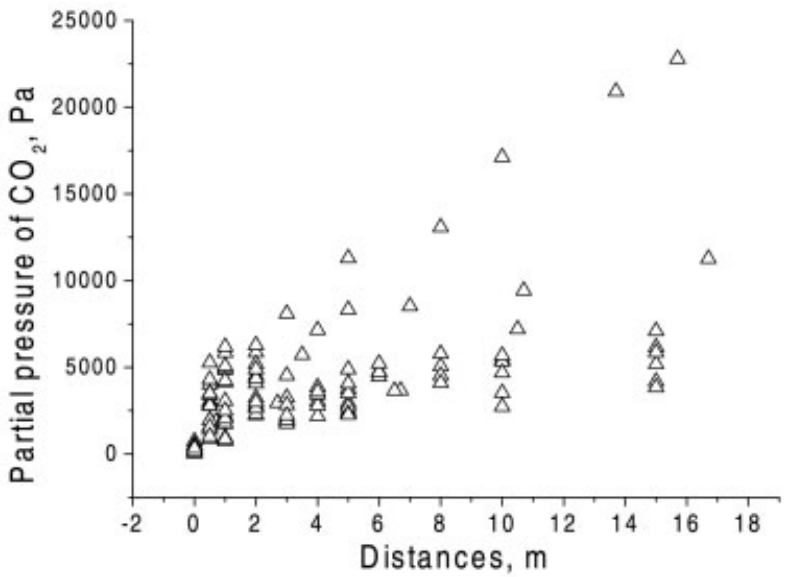

Fig. 4: The partial pressure of $\mathrm{CO}_{2}$ in the ditch water and subsurface water, where $0 \mathrm{~m}$ signifies ditch water and other distances signify spots in the subsurface water of reed beds.

$\mathrm{CO}_{2}$-Partialdruck im Kanalwasser und Bodenwasser. Die Abszissenabstände in $\mathrm{m}$ beziehen sich auf die Grenze zwischen Kanal und Röhrichtbeet.

$\mathrm{CO}_{2}$ in the subsurface water progressively increased with distance (Fig. 4).

Dissolved oxygen (DO) in ditch water samples was supersaturated and ranged from 15.8 to $19.3 \mathrm{mg} / \mathrm{L}$ (Table 3). The mean partial pressure was $46279 \mathrm{~Pa}$, which is 2.2 times of the atmospheric $\mathrm{O}_{2}$ pressure. In the subsurface water, the measured concentration values were between $0.27 \mathrm{mg} / \mathrm{L}$ and $4.60 \mathrm{mg} / \mathrm{L}$. Half of the data were lower than $1 \mathrm{mg} / \mathrm{L}$ in the subsurface water at $8 \mathrm{~m}$ distance (Fig. 5). A tendency for $\mathrm{O}_{2}$ to increase occurred from 0.5 to $8 \mathrm{~m}$, and the partial pressure increased from 672 to $10342 \mathrm{~Pa}, 5 \ldots 34 \%$ of atmospheric $\mathrm{O}_{2}$ pressure.

\subsection{The hydrochemical type change be- tween ditch water and subsurface water}

The main hydrochemical type is $\mathrm{C}_{1}^{\mathrm{Na}}$ for the ditch water and $\mathrm{C}_{\text {III }}^{\mathrm{Ca}}$ for the subsurface water according to one of the most widespread hydrochemical classification method by Alekin (Алёкин) [20]. This reflects the difference between dominant cations and the proportional relationships between ions. The hydrochemical type change occurred at $0.5 \mathrm{~m}$ landward away from ditch water except for two sites, whose hydrochemical type change between ditch water and subsurface water was slow and occurred at $2 \mathrm{~m}$ and $2.7 \mathrm{~m}$. The hydrochemical type specific for subsurface water generally remained invariable over a large distance and a wide total ion content range, $727 \ldots 2029 \mathrm{mg} / \mathrm{L}$.

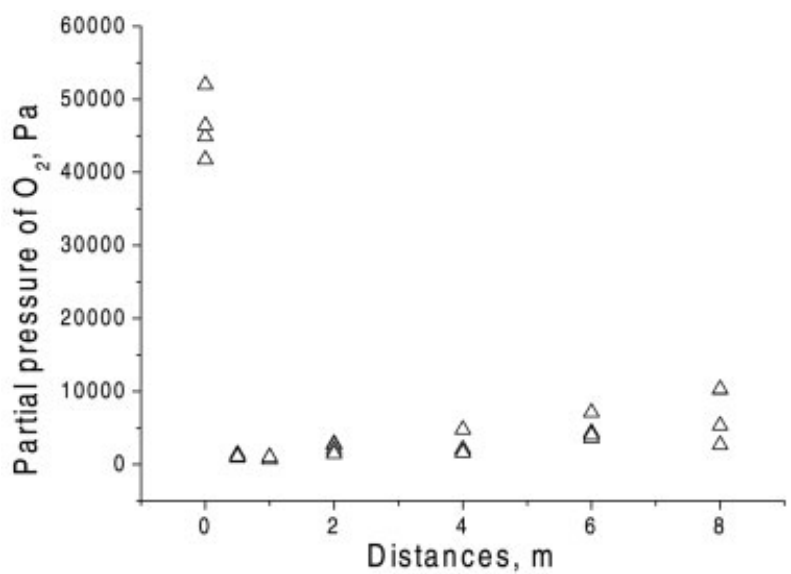

Fig. 5: The partial pressure of dissolved oxygen in the ditch water and subsurface water of reed bed during four different days, where $0 \mathrm{~m}$ signifies ditch water and other distances signify the spots in the subsurface water of reed bed.

$\mathrm{CO}_{2}$-Partialdruck im Kanalwasser und Bodenwasser an vier verschiedenen Tagen. Die Abszissenabstände in $\mathrm{m}$ beziehen sich auf die Grenze zwischen Kanal und Röhrichtbeet.

\subsection{Nutrients}

Most nutrient data in the ditch water were greater than the standard values for 5 th grade of surface water (Table 2). Ammonium $\left(\mathrm{NH}_{4}^{+} \mathrm{N}\right)$ concentrations in the ditch water were between $0.245 \mathrm{mg} / \mathrm{L}$ and $17.6 \mathrm{mg} / \mathrm{L}$, where $59 \%$ of the data exceeded the 5 th grade value. Ammonium nitrogen represented $(47 \pm 24) \%$ of total nitrogen. Nitrite $\left(\mathrm{NO}_{2}^{-}-\mathrm{N}\right)$ and nitrate $\left(\mathrm{NO}_{3}^{-} \mathrm{N}\right)$ concentration in the ditch water ranged between $0.054 \ldots 0.349 \mathrm{mg} / \mathrm{L}$ and $0.096 \ldots 1.61 \mathrm{mg} / \mathrm{L}$, respectively. TN values in the ditch water varied at a large scale, $1.95 \ldots 35.8 \mathrm{mg} / \mathrm{L}$. The highest total reactive phosphorus (TRP) concentration measured in the ditch water was $0.921 \mathrm{mg} / \mathrm{L}$ and several values in certain sites were below detection limit $(<0.01 \mathrm{mg} / \mathrm{L})$. TP concentrations in the ditch water ranged from 0.062 to $1.26 \mathrm{mg} / \mathrm{L}$, and $82 \%$ of the data exceeded the standard value.

In contrast to the values in the ditch water, the concentrations in the subsurface water showed greater variations. In particular, the CVs for inorganic nutrients were the greatest, with a range of $122.8 \ldots 167.1 \%$ (Table 3 ). The mean nutrient concentrations in the subsurface water were substantially lower than those in the ditch water. With the reed beds acting as filters, $\mathrm{NH}_{4}{ }^{+} \mathrm{N}, \mathrm{TN}, \mathrm{TRP}$ and TP decreased dramatically (Fig. 6 ), where mean concentrations in the subsurface water were $3.5 \%, 7.6 \%, 6.2 \%$, and $14.0 \%$ of those in the ditch water. Although $\mathrm{NO}_{2}^{-} \mathrm{N}$ and $\mathrm{NO}_{3}^{-}-\mathrm{N}$ concentrations also decreased with distance, the data points were dispersive. The corre- 

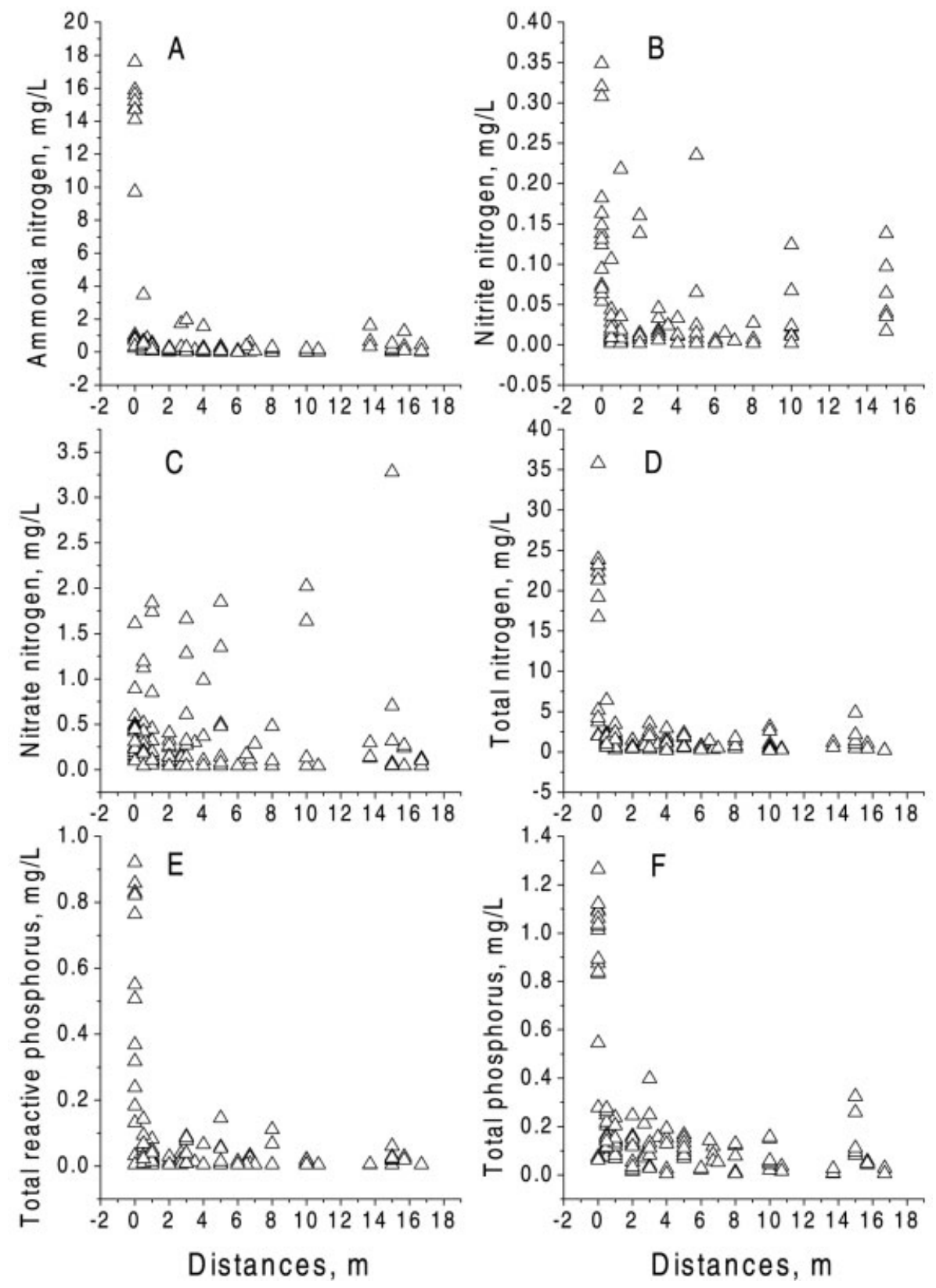

Fig. 6: The concentrations of nutrients in the ditch water and subsurface water. Distance $0 \mathrm{~m}$ signifies ditch water, and other distances signify the spots in the subsurface water of reed beds.

Nährstoffkonzentrationen im Kanalwasser und Bodenwasser. Die Abszissenabstände in $m$ beziehen sich auf die Grenze zwischen Kanal und Röhrichtbeet.

sponding mean concentrations in the subsurface water were $17.1 \%$ and $83.3 \%$ of those in the ditch water. The nutrient concentrations decreased sharply at $0.5 \mathrm{~m}$ landward from ditch water. The calculated mean nutrient concentrations at $0.5 \mathrm{~m}$ from ditch water are $\mathrm{NH}_{4}^{+}-\mathrm{N}, 0.513 \mathrm{mg} / \mathrm{L}, \mathrm{NO}_{2}^{-}-\mathrm{N}$, $0.020 \mathrm{mg} / \mathrm{L}, \mathrm{NO}_{3}^{-} \mathrm{N}, 0.346 \mathrm{mg} / \mathrm{L}, \mathrm{TN}, 1.608 \mathrm{mg} / \mathrm{L}, \mathrm{TRP}$, $0.035 \mathrm{mg} / \mathrm{L}, \mathrm{TP}, 0.162 \mathrm{mg} / \mathrm{L}$, which are $6.0 \%, 12.9 \%, 82.2 \%$, $10.2 \%, 9.1 \%$, and $20.9 \%$ of the values in the ditch water, respectively.

\section{Discussion}

Due to the sensitivity of areas with groundwater-surface water exchange to environmental change [2], many investigators use chemical characteristics of both groundwater and surface water to determine their interaction. In this study, we focused on the interface between the ditch water and reed beds. We proposed that the water and solute exchange at the boundary between lake and land is a process of gradual vari- 
ation. In the reed-bed/ditch landscape of Baiyangdian Lake, ditches are the landward boundary of lake water and reed beds are the lakeward boundary of land. Frequently there are other hydrophytes distributed between reed beds and ditches. The water and matter movement in the reed-bed/ditch systems can be either unidirectional or bidirectional. The subsurface transfer of water and materials is primarily unidirectional across the terrestrial boundary. In contrast, it is bidirectional across the aquatic boundary [2]. The reed beds are likely a sink for some elements and a source for others. We examined the hydrochemical characteristics of subsurface water in the reed beds and the retention of nutrients in ditch water.

The water level of Baiyangdian Lake fluctuates with hydrological conditions. The catchment discharges water into Baiyangdian Lake aperiodically and it causes the lake water level to fluctuate. The water level fluctuates slightly near the edge of reed beds due to the wind effect. There are dense macropores formed by the dead and living rhizomes in the reed soil. In our observation, the fluctuant lake water can quickly flow through the porous edge area and enhance the exchange of water, ions and nutrients. The lake contains about $2.30 \cdot 10^{8} \mathrm{~m}^{3}$ water at $8 \mathrm{~m}$ sea level [21]. Because there are 3700 ditches in the lake and the total edge area adds up to around $3.05 \cdot 10^{7} \mathrm{~m}^{2}$ at $8 \mathrm{~m}$ sea level, the fluctuation of $5 \mathrm{~cm}$ in lake level caused by a upstream flow or a windy day may cause water exchange of approximately $1.5 \cdot 10^{6} \mathrm{~m}^{3}$ between the lake and the reed beds. The Fuhe River with a total length of $62 \mathrm{~km}$ produces an annual mean discharge of $1.69 \cdot 10^{8} \mathrm{~m}^{3}$ entering the lake [21], mainly concentrated in summer. When heavily polluted river water passes through the lake area teemed with crisscrossed ditches and reed beds, the water quality is improved. That is probably the reason why the central lake has a better water quality.

In the ditch water, the change of partial $\mathrm{CO}_{2}$ pressure over a large scale is mainly controlled by the photosynthesis intensity as influenced by differences in seasonal water temperature. Ditch water often becomes greatly under-saturated in $\mathrm{CO}_{2}$ by photosynthesis because $\mathrm{CO}_{2}$ assimilation is faster than the resupply by gas exchange from the atmosphere.

Because of respiration by organisms, the $\mathrm{CO}_{2}$ concentration in some soils was found to be at most a few hundred times higher than that in the atmosphere in previous studies [22]. In our studies, the $\mathrm{CO}_{2}$ concentrations in the subsurface water of reed beds might be as high as $10 \ldots 11 \mathrm{mmol} / \mathrm{L}$. So the subsurface water of reed beds is a large reservoir of $\mathrm{CO}_{2}$ of varied partial pressure. Processes inside the reed beds, such as root excretions, microorganism activities, and the dissolution of carbonate may produce carbon dioxide. The $\mathrm{CO}_{2}$ produced by the reed community during growth is transported to the deep soil layer through the rooting system of reeds and ending in the subsurface water. Field investigation shows there are many rhizomes and dead root cavities distributed under the reed beds. They can transport water quickly to far distances. The root channel may serve as unidirectional passage for $\mathrm{CO}_{2}$ transport, which is equivalent to a "carbon dioxide pump". A large quantity of $\mathrm{CO}_{2}$ is transported and accumulated into the subsurface water by this pump.

The concentration of dissolved oxygen in water varies with environmental factors [10]. Baiyangdian Lake is eutrophic with high primary productivity. The DO concentrations in the ditch water were high $(15.80 \ldots 19.29 \mathrm{mg} / \mathrm{L})$ in day time due to strong photosynthesis. In contrast with $\mathrm{CO}_{2}$, the partial pressure of dissolved oxygen in the subsurface water is low. Aquatic macrophytes release oxygen from roots which influences the biogeochemical cycles in the sediments due to the effects on the redox status of the sediments [23, 24]. Qualitatively this is visualized by the reddish color associated with oxidized forms of iron on the soil surface of the reed roots. Many wetland plants have organs with airways from their above-water parts to their roots for root metabolism. Formation of lacunae and/or aerenchyma tissue is a characteristic feature of non-woody wetland plants [25, 26]. In anaerobic soils, oxygen is transferred to the roots primarily for plant respiration [27] and only excess oxygen is leaked to the microzone at the rhizosphere. The respiratory oxygen consumption of the roots and rhizomes almost perfectly balanced the oxygen influx through the cavities of dead, still standing culms of Phragmites australis leaving only $0.02 \mathrm{~g} /\left(\mathrm{m}^{2} \mathrm{~d}\right)$ of oxygen to be released to the surrounding soil $[27,28]$. This may explain the low $\mathrm{O}_{2}$ content in the subsurface water.

Calcium and magnesium gradients were affected by the calcareous property of reed beds soil. Due to the effect of wastewater from Fuhe River, the river mouth water contains more $\mathrm{Na}^{+}$than other cations. Although there is an exchange at the boundary area of reed-bed/ditch ecotones, the dominant cation in the subsurface water is generally $\mathrm{Ca}^{2+}$. Hardness and alkalinity compose the buffering mechanisms that determine most physical and chemical properties in the subsurface water of reed beds. The strong buffering action of carbon dioxide and carbonate equilibrium system determines the fact that the variations of $\mathrm{pH}$ values in the subsurface water are limited $(6.67 \ldots 7.67)$.

Although the waters are connected via meandrous ditches, the nutrient concentrations in the ditch water varied with different sites. This may be caused by the compartment of crisscrossed ditches and reed bed systems.

According to the commonly accepted standards for Lake Eutrophication Control, many indices in Baiyangdian Lake greatly exceeded the standard values. However, when the ditch water infiltrates the reed bed soil, a great decrease generally occurs. This filtering effect of reed-bed/ditch interface seems unidirectional at the terrestrial boundary and bidirectional across the aquatic boundary. Both boundaries appear to be major locations for regulating and diminishing the trans- 
fer of inorganic nitrogen and phosphorus from subsurface water to ditch water [29].

The total nitrogen mass removal rate in natural wetlands is highly variable and depends on the form of nitrogen in the inflow, water depth, dissolved oxygen, and the total nitrogen mass loading rate. The efficiency of total nitrogen removal is reduced by low total nitrogen inflow concentration because of internal processes. At low inflow concentrations, the internal production and release of total nitrogen is greater than assimilation, resulting in negatively calculated total nitrogen removal efficiencies [10]. The increased nutrient concentrations in the central part of reed beds compared to the edge part may result from a higher internal TN release than assimilation. The process of nitrification consumes alkalinity and denitrification produces alkalinity [10]. The interaction between nitrification and denitrification maintains the concentration of alkalinity.

Phosphorus removal in wetlands takes place due to many mechanisms [30-36]. Since $P$ is retained within the wetland, its ultimate removal from the system is achieved by harvesting the plants and removing the saturated root bed media. However, before plant uptake, soil sorption capacity is huge [37]. High concentrations of calcium in subsurface water can form complex indissoluble compounds with phosphate, such as apatite, hydroxyapatite, and carbonato apatite [22]. This high hardness can partly explain the low concentrations of phosphorus in the subsurface water.

In Baiyangdian Lake, the ditch/reed beds landscape structure greatly increases the interaction between the eutrophic river mouth water and reed beds root zone. The ditch water can flow to far distances under the influence of the reed community root zone; in addition, ditch water provides reeds with sufficient water and nutrients. The ecotone structures located between the river and open lake water act as a significant buffer zone to reduce the harmful impacts of pollutant load. Local people have consistently maintained the existence of this landscape pattern. A traditional cultivation system of matter recycling exists in Baiyangdian Lake. The farmers dredge the sediments from the ditches and shallow parts of the lake and cover the reed fields with the mud in winter once every four or five years. In the fall, reeds are harvested by farmers and used as raw materials for family mat production or rural enterprises. Grasses are also harvested for livestock forage and small reeds are used as family fuel. The specific reed-bed/ ditch distribution and cultivation system can effectively prevent the degeneration of reed community and maintain the longevity of wetland ecosystem.

\section{Conclusions}

Baiyangdian Lake has a broad reed-bed/ditch interaction area, in which reed beds and ditches are the extension of ter- restrial boundary and aquatic boundary, respectively. The reed bed system has strong buffering function for chemical ions and nutrients, and maintains internal invariability despite the outer concentrations in the ditch water. The hydrochemical characteristics of the subsurface water in reed beds showed high concentrations of $\mathrm{CO}_{2}$, hardness and alkalinity and low concentrations of dissolved oxygen. At $0.5 \mathrm{~m}$ landward away from ditch water, the hydrochemical type change of subsurface water occurs and the dominant cation changes from $\mathrm{Na}^{+}$to $\mathrm{Ca}^{2+}$. The greatest nutrient retention also occurs at the initial $0.5 \mathrm{~m}$ away from ditch water. The interface of reed-bed/ditch system greatly increases the active area between ditch water and subsurface water and helps to maintain the stability of the lake ecosystem.

\section{Acknowledgements}

Funding for this research was provided by the National Natural Sciences Foundation of China (39970152, 59978051). We gratefully thank Haiying Chen, and Jing Jiang in the Baoding City Environmental Monitor Station of Hebei Province for their assistance in water sample analyses. The authors would like to thank Dr. Cindy J. Lin, a visiting scientist from USEPA, for editorial comments and language corrections.

\section{References}

[1] Tiner, R. W.: Wetlands are ecotones: reality or myth? In: Gopal, B., Hillbricht-Ilkowska, A., Wetzel, R. G. (Eds.).: Wetlands and Ecotones: Studies on Land-Water Interactions. Nat. Inst. Ecol., New Delhi, India, 1993, pp. 1-15.

[2] Naiman, R. J., Décamps, H.: The ecology of interfaces: Riparian zones. Annu. Rev. Ecol. Syst. 28, 621-658 (1997).

[3] MacDonald, H. F., Bergstrom, J. C., Houston, J. E.: A proposed methodology for measuring incremental environmental benefits from using constructed wetlands to control agricultural non-point-source pollution. J. Environ. Manage. 54 (4), 259-267 (1998).

[4] Hunt, P. G., Stone, K. C., Humenik, F. J., Matheny, T. A., Johnson, $M$. H.: In-stream wetland mitigation of nitrogen contamination in a USA coastal plain stream. J. Environ. Qual. 28 (1), 249-256 (1999).

[5] Uusi-Kämppä, J., Braskerud, B., Jansson, H., Syversen, N., Uusitalo, R.: Buffer zones and constructed wetlands as filters for agricultural phosphorus. J. Environ. Qual. 29, 151158 (2000).

[6] Withers, P. J. A., Davidson, I. A., Foy, R. H.: Prospects for controlling nonpoint phosphorus loss to water: a UK perspective. J. Environ. Qual. 29, 167-175 (2000). 
[7] Yin, C. Q., Shan, B. Q.: Multipond systems: a sustainable way to control diffuse phosphorus pollution. Ambio 30 (6), 369-375 (2001).

[8] Naiman, R. J., Décamps, H. (Eds.): The Ecology and Management of Aquatic-Terrestrial Ecotones. UNESCO, Paris, and Parthenon Publishing, Carnforth, 1990.

[9] Malanson G. P.: Riparian Landscapes. Cambridge Univ. Press, Cambridge, UK, 1993.

[10] Kadlec, R. H., Knight, R. L.:Treatment Wetlands. CRC Press/ Lewis Publishers, Boca Raton, Florida, USA, 1996, pp. 281-310, 373-478, 483-484.

[11] Eser, P., Rosen, M. R.:The influence of subsurface water hydrology and stratigraphy on the hydrochemistry of Stump Bay, South Taupo Wetland, New Zealand. J. Hydrol. 220, 27-47 (1999).

[12] Hite, C. D., Cheng, S. L.: Spatial characterization of hydrogeochemistry within a constructed fen, Greene County, Ohio. Ground Water, 34 (3), 415-424 (1996).

[13] Mendelssohn, I. A., Sorrell, B. K., Brix, H., Schierup, H. H., Lorenzen, B., Maltby, E.:Controls on soil cellulose decomposition along a salinity gradient in a Phragmites australis wetland in Denmark. Aquat. Bot. 64, 381-398 (1999).

[14] Hunt, R. J., Krabbenhoft, D. P., Anderson, M. P.:Groundwater inflow measurements in wetland systems. Water Resour. Res. 32 (3), 495-507 (1996).

[15] Yin, C., Lan, Z.:The nutrient retention by ecotone wetlands and their modification for Baiyangdian Lake restoration. Water Sci. Technol. 32 (3), 159-167 (1995).

[16] APHA: Standard Methods for the Examination of Water and Wastewater, 16th edition. American Public Health Association, NW, Washington, DC, 1985, pp. 143-488.

[17] Ebina, J., Tsutsui, T., Shirai, T.: Simultaneous determination of total nitrogen and total phosphorus in water using peroxodisulfate oxidation. Water Res. 17, 1721-1726 (1983).

[18] Tang, H. X.: Chemical Principles of Water and Wastewater. China Architecture and Building Press, Beijing, China, 1979, pp. 97-111. (In Chinese).

[19] NEPA: Environmental Quality Standard for Surface Water GHZB 1-1999. National Environmental Protection Agency (China), 1999, pp. 1-7. (In Chinese).

[20] Alekin, O. A.: Basic Hydrochemistry. Leningrad: Gidrometeoizdat, 1970. (In Russian).

[21] The Chronicle Office of Anxin County (Ed.): The Local Chronicles of Baiyangdian Lake. Cathay Book Shop Press, Beijing, 1996, pp. 13-25. (In Chinese).

[22] Stumm, W., Morgan, J. J.: Aquatic Chemistry. 2nd Edition. Wiley Interscience, New York, 1981, pp. 171-229.

[23] Barko, J.W., Gunnison, D., Carpenter, S. R.:Sediment interactions with submerged macrophyte growth and community dynamics. Aquat. Bot. 41, 41-65 (1991).
[24] Sorrel, B. K., Boon, P. I.: Biogeochemistry of billabond sediments - seasonal variations in methane production. Freshwater Biol. 27, 435-445 (1992).

[25] Guntenspergen, G. R., Stearns, F., Kadlec, J. A.: Wetland vegetation. In: Hammer, D. A. (Ed.): Constructed Wetlands for Wastewater Treatment. Lewis Publishers, Chelsea, Michigan, 1990, pp. 73-88.

[26] Sundaravadivel, M., Vigneswaran, S.: Constructed wetlands for wastewater treatment. Crit. Rev. Environ. Sci. Technol. 31 (4), 351-409 (2001).

[27] Brix, H.: Gas exchange through the soil-atmosphere interphase and through dead culms of Phragmites australis in a constructed reed bed receiving domestic sewage. Water Res. 24, 259-266 (1990).

[28] Brix, H., Schierup, H. H.: Soil oxygenation in constructed reed beds. In: Cooper, P. F., Findlater, B. C. (Eds.): Constructed Wetlands in Water Pollution Control. Pergamon Press, Oxford, 1990, pp. 53-65.

[29] McClain, M. E., Richey, J. E., Pimentel, T. P.:Groundwater nitrogen dynamics at the terrestrial-lotic interface of a small catchment in the Central Amazon Basin. Biogeochemistry 27, 113-127 (1994).

[30] Greenway, M., Woolley, A.: Constructed wetlands in Queensland: performance efficiency and nutrient bioaccumulation. Ecol. Eng. 12, 39-55 (1999).

[31] Kadlec, R. H.: An autobiotic wetland phosphorus model. Ecol. Eng. 8, 145-172 (1997).

[32] Newbold, D. J., Elwood, J. W., O'Neil, R. V., Sheldon, A. L.: Phosphorus dynamics in a woodland stream ecosystem: a study of nutrient spiraling. Ecology 64, 1249-1263 (1983).

[33] Reddy, K. R., Kadlec, R. H., Flaig, E., Gale, P. M.: Phosphorus retention in streams and wetlands: a review. Crit. Rev. Environ. Sci. Technol. 29, 83-146 (1999).

[34] Tanner, C. C., Sukias, J. P. S., Upsdell, M. P.: Relationships between loading rates and pollutant removal during maturation of gravel-bed constructed wetlands. J. Environ. Qual. 27, 448-458 (1998).

[35] Reddy, K. R., Tucker, J. C., DeBusk, W. F.:The role of Egeria in removing nitrogen and phosphorus from nutrient enriched waters. J. Aquat. Plant Manage. 25, 14-19 (1987).

[36] Diaz, O. A., Reddy, K. R., Moore, P. A.: Solubility of inorganic $\mathrm{P}$ in stream water as influenced by $\mathrm{pH}$ and $\mathrm{Ca}$ concentration. Water Res. 28, 1755-1763 (1994).

[37] Casey, R. E., Taylor, M. D., Klaine, S. J.: Mechanisms of nutrient attenuation in a subsurface flow riparian wetland. J. Environ. Qual. 30, 1732-1737 (2001).

[Received: 25 March 2002; accepted: 14 June 2002] 